\title{
Sleep quality and its association with menopausal and climacteric symptoms
}

\author{
Qualidade do sono e sua associação com os sintomas de menopausa e climatério \\ Calidad del sueño y su asociación con síntomas menopáusicos y climatéricos
}

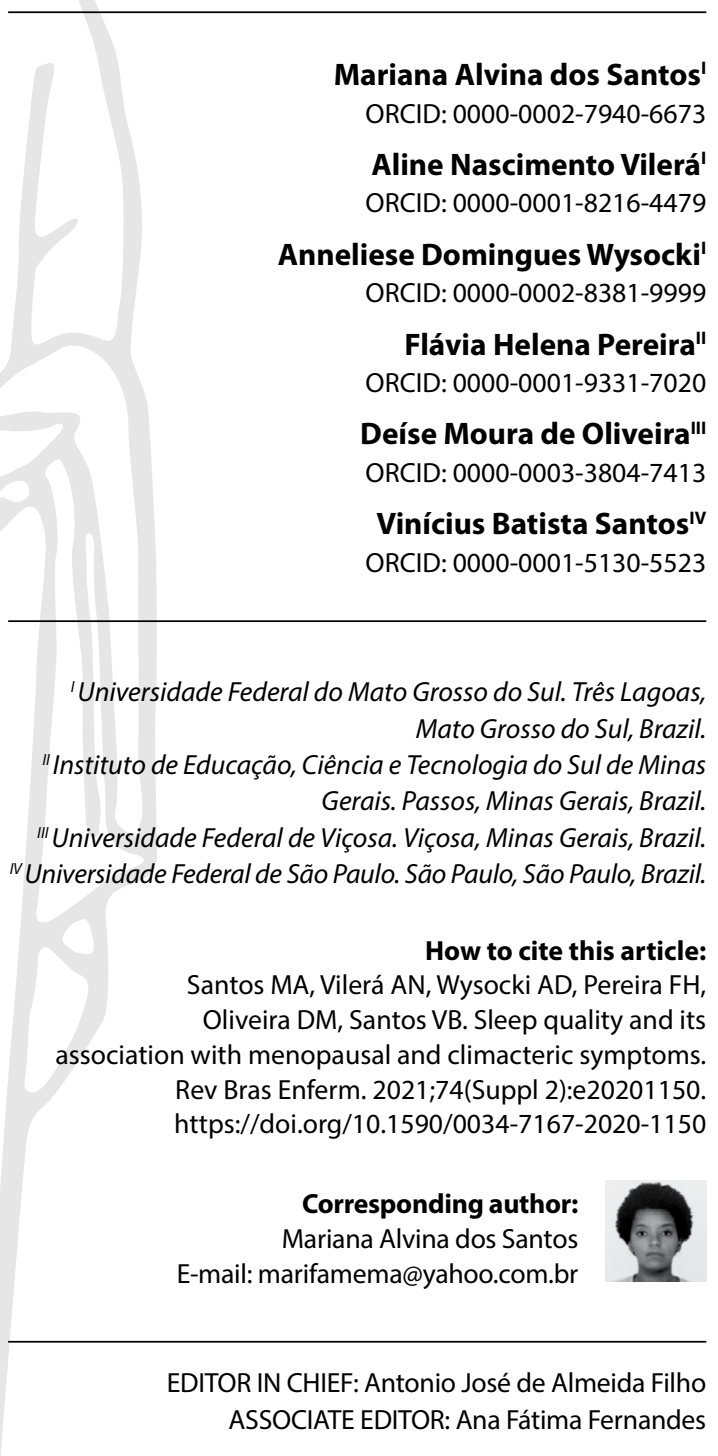

Submission: $11-23-2020$

Approval: 02-09-2021

\begin{abstract}
Objective: to assess sleep quality in menopausal women and its association with symptoms related to this period. Method: this is a cross-sectional, analytical and correlational study. Sleep was assessed using the Pittsburgh Sleep Quality Index; and climacteric symptoms, according to the Menopause Rating Scale. To compare the total score and each Menopause Rating Scale domain with the PSQI classification, the Mann-Whitney U non-parametric test was used. $P<0.05$ was considered significant. Results: 261 women (67.8\%) were classified as bad sleepers. There was a positive and significant correlation between the sleep scale scores and the total menopause score and its domains. Women categorized as poor sleepers had worse scores on the menopause symptom scale. Conclusion: women with worse sleep quality revealed greater severity of symptoms related to menopause.

Descriptors: Menopause; Postmenopause; Sleep; Nursing; Climacteric.
\end{abstract}

\section{RESUMO}

Objetivo: Avaliar a qualidade do sono em mulheres menopausadas e sua associação com os sintomas relacionados a esse período. Método: Estudo transversal, analítico e correlacional. O sono foi avaliado por meio do Índice de Qualidade do Sono de Pittsburgh; e os sintomas do climatério, pelo Menopause Rating Scale. Para a comparação do escore total e de cada domínio do Menopause Rating Scale com a classificação do Índice de Qualidade do Sono de Pittsburgh (PSQI), foi utilizado o teste não paramétrico U de Mann-Whitney. Considerouse valor $p<0,05$ como significante. Resultados: Foram classificadas 261 mulheres $(67,8 \%)$ como más dormidoras. Houve correlação positiva e significativa dos escores da escala do sono com o escore total da menopausa e seus domínios. As mulheres categorizadas como más dormidoras apresentaram piores escores na escala de sintomas de menopausa. Conclusão: Mulheres com pior qualidade do sono revelaram maior severidade dos sintomas relacionados à menopausa.

Descritores: Menopausa; Pós-Menopausa; Sono; Enfermagem; Climatério.

\section{RESUMEN}

Objetivo: evaluar la calidad del sueño en mujeres menopáusicas y su asociación con síntomas relacionados con este período. Método: estudio transversal, analítico y correlacional. El sueño se evaluó mediante el índice de calidad del sueño de Pittsburgh; y síntomas climatéricos, según la escala de calificación de la menopausia. Para comparar la puntuación total y cada dominio Menopause Rating Scale con la clasificación PSQI, se utilizó la prueba no paramétrica $U$ de Mann-Whitnney. $\mathrm{P}<0,05$ se consideró significativo. Resultados: 261 mujeres $(67,8 \%)$ fueron clasificadas como mal durmientes. Hubo una correlación positiva y significativa entre las puntuaciones de la escala de sueño y la puntuación total de la menopausia y sus dominios. Las mujeres clasificadas como personas que duermen mal tuvieron peores puntuaciones en la escala de síntomas de la menopausia. Conclusión: las mujeres con peor calidad del sueño revelaron una mayor gravedad de los síntomas relacionados con la menopausia. Descriptores: Menopausia; Posmenopausia; Sueño; Enfermería; Climaterio. 


\section{INTRODUCTION}

Since the last decades of the twentieth century, Brazil has undergone important transformations in the structure and dynamics of its population. The progressive reduction in mortality, associated with the decrease in the fertility rate, has configured an increasingly aging population with a decrease in the number of young people ${ }^{(1)}$. With regard to women's health, this demographic transition reflects a progressive number of menopausal/ climacteric women and provides new demands for the health sector, as well as strengthening the implementation of public policies, such as the Brazilian National Policy for Comprehensive Care for Women's Health (PNAISM - Política Nacional de Atenção Integral à Saúde da Mulher), which highlights the importance of assistance to women at this life cycle stage ${ }^{(2)}$.

Climacteric is an important transition period in a woman's life, consisting of pre-menopause, menopause and post-menopause. Menopause is characterized by the absence of menstruation, for 12 consecutive months, due to the decrease in ovarian hormones (estrogen and progesterone) and, commonly, occurs in women between 45 and 55 years of age. In Brazil, 13.6\% of menopausal women are in this age group ${ }^{(3-4)}$.

In response to the deterioration of ovarian function, endocrinological changes occur gradually and nonlinearly in menopausal women. In association with the fluctuation and gradual decline of estrogen, symptoms of menopause arise, including vasomotor (hot flashes and sweating), sleep disturbances and symptoms of mood swings ${ }^{(3)}$.

Sleep disorders are one of the most troublesome of menopause symptoms and are reported by 39 to $47 \%$ of menopausal women ${ }^{(5)}$. Sleep dysfunctions can be classified as difficulty sleeping, waking up at night and waking up earlier than normal ${ }^{(6)}$. Elevated cortisol levels affect mood and sleep quality of women in the climacteric period due to the high peak of stress. The decrease in the level of estrogen also interferes with vasomotor symptoms, which cause hot flash waves in the face and in the anterior thoracic region, accompanied by sweating. This usually occurs during the night, which contributes to poor sleep quality ${ }^{(7)}$.

The presence and worsening of signs and symptoms related to menopause, associated with poor sleep quality, possibly lead to the onset or intensify other diseases such as anxiety/depression, in addition to vasomotor and sexual symptoms, which can negatively impact autonomy and independence in the daily chores and in the quality of life of women ${ }^{(3,8)}$.

Knowledge of sleep patterns in menopausal women corroborates the construction of nursing knowledge so that coping strategies and identification of interventions can be established and investigated. Moreover, it can benefit symptomatic women by proposing measures to better manage the problems caused by this period and direct the construction of public policies in this area.

Given the above, the guiding question that guided this study was: are symptoms related to menopause associated with worsening sleep quality? Thus, the hypothesis was that women with greater severity of symptoms related to menopause have worse sleep quality.

\section{OBJECTIVE}

To assess sleep quality in menopausal women and its association with symptoms related to this period.

\section{METHODS}

\section{Ethical aspects}

The study complied with Resolution 466/12 of the Brazilian National Health Council (CNS - Conselho Nacional de Saúde) and was approved by the Ethics Committee of Universidade Federal do Mato Grosso do Sul. The risk of participating in this study was related to the risk of a psychological nature; however, the following prevention/minimization measures were adopted: interviewers were trained to conduct the interview and, if necessary, the interview was suspended.

\section{Study design, period, and location}

This is a cross-sectional, analytical and correlational study, which was based on the guidelines of the Strengthening The Reporting of Observational Studies in Epidemiology (STROBE) ${ }^{(9)}$. Data collection was carried out from April 2019 to January 2020, with women attended in all four (04) primary health units and one (01) secondary level (women's clinic) in the municipality of Três Lagoas/MS that performed gynecological and specific care for women's health.

\section{Population or sample; inclusion and exclusion criteria}

The convenience sample was composed of women over 45 years old, with minimal amenorrhea for 12 months and without drug treatment for menopause. Those who were unable to understand the instructions, who underwent hysterectomy and night workers, were excluded because they had a sleep pattern that had already changed as a result of work activity.

To carry out the sample calculation, the estimated number of women aged 45 years or over who lived in the municipality of Três Lagoas/MS was used as a basis; to this end, a survey was developed using data from IBGE (Brazilian Institute of Geography and Statistics - Instituto Brasileiro de Geografia e Estatística) and the number of 13,840 women in this age group was identified. From this and considering the parameters: sampling error of $0.05,95 \%$ confidence interval and $P$ (population proportion) of $50 \%$, the minimum sample was calculated, which was corrected because it is a finite population, obtaining as a minimum sample the quantity of 373 women aged over 45 years to be interviewed.

\section{Study protocol}

For the invitation and data collection, the researchers attended the selected health services in order to obtain women eligible to participate in the research. Selection was random and women who met the eligibility criteria received an explanation as to the objectives of the study. Those who agreed to participate in the study signed the Informed Consent Term (ICF), after which the data collection instruments were completed in an individual room. 
In the data collection, a sociodemographic characterization questionnaire - was used, containing information about age in years, income, education, marital status, religion, occupation, race - and women's clinic (sexual life and symptoms of menopause). To assess sleep quality, considered in this study as a dependent variable, the Pittsburgh Sleep Quality Index (PSQI) instrument was used, which consists of 19 self-administered questions, grouped into seven components: subjective sleep quality; sleep latency; sleep duration; habitual sleep efficiency; sleep disorders; use of sleeping medication; daytime sleepiness and disturbances during the day. The scores of the seven components were added to give an overall PSQI score, which ranges from 0 to 21 (the higher the score, the worse sleep quality). As good sleepers, those with scores $\leq 5$ are categorized; and as bad sleepers, those with scores $>5^{(10)}$.

The Menopause Rating Scale (MRS) instrument was used to assess menopausal symptoms, consisting of eleven items that assess climacteric symptoms, distributed over three subscales: Somatic, Psychological and Urogenital ${ }^{(11)}$. To achieve the total MRS scale score, the scores of the three subscales were added and the symptoms were classified as asymptomatic (0-4 points), mild (5 to 8 points), moderate (9-15 points) and severe (more than 16 points). With regard to the classification of each subscale, the somatovegetative domain was classified as asymptomatic or scarce - when two or less points were obtained; light, 3 to 4 points; moderate, 5 to 8 points; severe, more than 9 points. In the psychological domain: asymptomatic up to 1 point; light, 2 to 3 points; moderate, 4 to 6 points; severe, more than 7 points; and, in the urogenital domain, asymptomatic, when no stitches were obtained; light (1 point); moderate ( 2 to 3 points); severe (more than 4 points) $)^{(12)}$. The total score of this instrument can vary from zero (no symptoms) to 44 (maximum symptoms). The instruments were filled out only with respondents' initials in order to avoid their identification and numbered sequentially. There was no link between the researchers and the health services where the study was conducted.

\section{Analysis of results, and statistics}

The data were entered into the Microsoft Excel software and subsequently transferred to the SPSS version 22.0 program, where statistical analyzes were performed. The calculation of relative and absolute frequency was developed for categorical variables and the calculation of mean, standard deviation, median and $25^{\text {th }}$ and $75^{\text {th }}$ percentiles for quantitative variables.

Sleep quality was considered as a dependent variable; and the independent variable, the severity of menopausal symptoms. The PSQI score was compared with the score of the MRS instrument and its domains through Spearman's correlation, being assumed as a very weak correlation when below 0.20 ; weak, between 0.20 and 0.39 ; moderate, between 0.40 and 0.69 ; strong, between 0.70 and 0.89 ; very strong, above $0.90^{(13)}$.

To compare the total score and each domain of the MRS with the PSQI classification (good sleepers - with a score less than or equal to 5 points - and bad sleepers o with a score above 5 points), the nonparametric Mann-Whitney $\mathrm{U}$ test. A value of $\mathrm{p}$ $<0.05$ was considered statistically significant.

\section{RESULTS}

Thus, 700 women were considered potentially eligible to participate in the present study, of which 36 women refused to sign the ICF and 279 had some exclusion criteria ( 75 hysterectomized, 143 under 45 years old, 60 over 45 years old still menstruating and 1 night worker). The final sample consisted of 385 women, most of them between 45 and 55 years old $(41 \%)$, with a family income of up to 2 minimum wages $(70.9 \%)$, with a partner $(56.9 \%)$, incomplete elementary school (30\%) and complete (16\%), predominantly Catholic $(52.5 \%)$, without employment (61.3\%) and self-declared black (9.6\%) or mixed race $(45 \%)$ (Table 1$)$.

The women interviewed started menopause, on average, at 46 years old and reported as predominant symptoms, in the post-menopause phase, hot flash (67.8\%), mood swings (61\%), alopecia (54.5\%), sleep disturbance (53.8\%) and dyspareunia (51.9\%), as listed in Table 1.

Table 1 - Sociodemographic characteristics of menopausal women, Três Lagoas, Mato Grosso do Sul, Brazil, 2019

\begin{tabular}{|c|c|}
\hline Characteristics & $\mathrm{n}(\%)$ \\
\hline \multicolumn{2}{|l|}{ Age } \\
\hline 45 to 55 years old & $158(41)$ \\
\hline 56 to 65 years old & $135(35.1)$ \\
\hline$\geq 66$ years old & $92(23.9)$ \\
\hline \multicolumn{2}{|l|}{ Income (MW*) } \\
\hline 0 to 2 & $273(70.9)$ \\
\hline 3 to 4 & $80(20.8)$ \\
\hline$>5$ & $32(8.3)$ \\
\hline \multicolumn{2}{|l|}{ Marital status } \\
\hline With a partner & $219(56.9)$ \\
\hline Without a partner & $166(43.1)$ \\
\hline \multicolumn{2}{|l|}{ Educational level } \\
\hline Illiterate & $20(5.2)$ \\
\hline Incomplete/complete elementary school & $177(46)$ \\
\hline High school and incomplete/complete vocational education & $124(32.3)$ \\
\hline Incomplete/complete higher education & $64(6.7)$ \\
\hline \multicolumn{2}{|l|}{ Religion } \\
\hline Catholicism & $202(52.5)$ \\
\hline Evangelical & $148(38.4)$ \\
\hline Spiritist, another, and none & $35(9.1)$ \\
\hline \multicolumn{2}{|l|}{ Occupation } \\
\hline Employed & $149(38.7)$ \\
\hline Unemployed & $236(61.3)$ \\
\hline \multicolumn{2}{|l|}{ Race } \\
\hline White and yellow & $175(45.4)$ \\
\hline Black and brown & $210(54.6)$ \\
\hline \multicolumn{2}{|l|}{ Active sex life } \\
\hline Yes & $220(57.1)$ \\
\hline No & 165 (42.9) \\
\hline Early sex life, years, Mean (SD $\left.{ }^{\dagger}\right)$ & $18.6(4.68)$ \\
\hline Onset of menopause, Mean (SD ${ }^{\dagger}$ & $46.9(5.65)$ \\
\hline \multicolumn{2}{|l|}{ Clinical signs after menopause } \\
\hline Hot flash & $261(67.8)$ \\
\hline Mood swing & $235(61.0)$ \\
\hline Change in appetite & $99(25.7)$ \\
\hline Vaginal dryness & $152(39.5)$ \\
\hline Change in libido & $147(38.2)$ \\
\hline Dyspareunia & $200(51.9)$ \\
\hline Alopecia & $210(54.5)$ \\
\hline Sleep change & $207(53.8)$ \\
\hline Do not remember & $09(2.3)$ \\
\hline
\end{tabular}

${ }^{+} \mathrm{SD}=$ standard deviation 
Regarding the sleep pattern assessed by the PSQI instrument, 124 women (32.2\%) were classified as good sleepers and 261 (67.8\%) as bad sleepers.

The mean overall MRS score was 15.49 with a median of 15 , being classified as moderate symptoms. The somatovegetative, psychological and urogenital domains were classified as moderate, according to Table 2. It was observed that the symptoms with the highest scores were: shortness of breath, sweating and hot flash, muscle and joint problems, and irritability (Table 2).

Table 2 - Global score and each domain of the Menopause Rating Scale (MRS) of menopausal women, Três Lagoas, Mato Grosso do Sul, Brazil, 2019

\begin{tabular}{lcccc}
\hline Domains and indicators & Mean & SD* & Median & $\mathbf{2 5 ; 7 5}$ \\
\hline Somatovegetative domain & 6.79 & 3.85 & 7.0 & $4 ; 10$ \\
Shortness of breath, sweats, and hot flashes & 2.12 & 1.69 & 3.0 & $0 ; 4.0$ \\
Heart disease & 1.01 & 1.24 & 0 & $0 ; 2.0$ \\
Problems with sleeping & 1.55 & 1.60 & 1.0 & $0 ; 3.0$ \\
Muscle and joint problems & 2.12 & 1.69 & 3.0 & $0 ; 4.0$ \\
Psychological domain & 5.95 & 4.29 & 5.0 & $2.5 ; 9.0$ \\
Depressive mood & 0.98 & 1.28 & 0 & $0 ; 20$ \\
Irritability & 2.08 & 1.63 & 2.0 & $0 ; 4.0$ \\
Anxiety & 1.83 & 1.65 & 1.0 & $0 ; 4.0$ \\
Physical and mental exhaustion & 1.06 & 1.28 & 0 & $0 ; 20$ \\
Urogenital domain & 2.73 & 2.82 & 2.0 & $0 ; 4.5$ \\
Sexual problems & 0.94 & 1.35 & 0 & $0 ; 2$ \\
Bladder problems & 0.77 & 1.28 & 0 & $0 ; 1$ \\
Vaginal dryness & 1.02 & 1.32 & 0 & $0 ; 2$ \\
Global score & 15.49 & 8.57 & 15.0 & $9.5 ; 22$ \\
\hline
\end{tabular}

Note: ${ }^{*} \mathrm{SD}=$ Standard deviation; $25 ; 75-25^{\text {th }}$ and $75^{\text {th }}$ percentile.

Table 3 - Comparison of the Menopause Rating Scale (MRS) scores in the groups of good and bad menopausal women sleepers, Três Lagoas, Mato Grosso do Sul, Brazil, 2019

\begin{tabular}{|c|c|c|c|c|c|}
\hline \multirow[b]{2}{*}{ Domains and indicators } & \multicolumn{2}{|c|}{ Good sleepers } & \multicolumn{2}{|c|}{ Bad sleepers } & \multirow[b]{2}{*}{$\begin{array}{c}\boldsymbol{p} \\
\text { value }^{\dagger}\end{array}$} \\
\hline & $\begin{array}{l}\text { Mean } \\
\left(D^{*}\right)\end{array}$ & $\begin{array}{c}\text { Median } \\
(25 ; 75)\end{array}$ & $\begin{array}{c}\text { Mean } \\
\left(D^{*}\right)\end{array}$ & $\begin{array}{c}\text { Median } \\
(25 ; 75)\end{array}$ & \\
\hline Somatovegetative domain & $4.71(3.37)$ & $4.0(2 ; 7)$ & $7.78(3.67)$ & $8.0(5 ; 10)$ & $<0.01$ \\
\hline Shortness of breath, sweats, and hot flashes & $1.60(1.66)$ & $1.0(0 ; 3)$ & $2.38(1.65)$ & $3.0(0 ; 4)$ & $<0.01$ \\
\hline Heart disease & $0.73(1.12)$ & $0(0 ; 2)$ & $1.13(1.27)$ & $1.0(0 ; 2)$ & $<0.01$ \\
\hline Sleeping problems & $0.57(1.10)$ & $0(0 ; 1)$ & $2.01(1.60)$ & $2.0(0 ; 4)$ & $<0.01$ \\
\hline Muscle and joint problems & $1.81(1.80)$ & $1.0(0 ; 4)$ & $2.26(1.62)$ & $3.0(0 ; 4)$ & 0.39 \\
\hline Psychological domain & $3.49(3.21)$ & $3.0(0.25 ; 5.0)$ & $7.12(4.25)$ & $7.0(4 ; 11)$ & $<0.01$ \\
\hline Depressive mood & $0.35(0.78)$ & $0(0 ; 0)$ & $1.28(1.36)$ & $1.0(0 ; 2)$ & $<0.01$ \\
\hline Irritability & $1.52(1.61)$ & $1(0 ; 3)$ & $2.34(1.58)$ & $3.0(1 ; 4)$ & $<0.01$ \\
\hline Anxiety & $1.10(1.42)$ & $0(0 ; 2)$ & $2.18(1.64)$ & $2.0(0 ; 4)$ & $<0.01$ \\
\hline Physical and mental exhaustion & $0.52(0.94)$ & $0(0 ; 1)$ & $1.33(1.34)$ & $1.0(0 ; 2)$ & $<0.01$ \\
\hline Urogenital domain & $2.04(2.57)$ & $1.0(0 ; 3)$ & $3.06(2.88)$ & $3.0(0 ; 5)$ & $<0.01$ \\
\hline Sexual problems & $0.66(1.20)$ & $0(0 ; 0)$ & $1.07(1.39)$ & $0(0 ; 2)$ & $<0.01$ \\
\hline Bladder problems & $0.52(1.14)$ & $0(0 ; 0)$ & $0.89(1.32)$ & $0(0 ; 2)$ & $<0.01$ \\
\hline Vaginal dryness & $0.85(1.29)$ & $0(0 ; 2)$ & $1.10(1.33)$ & $0(0 ; 2)$ & 0.40 \\
\hline Global score & $10.25(6.57)$ & $10(5 ; 15)$ & $17.97(8.29)$ & $17(12 ; 25)$ & $<0.01$ \\
\hline
\end{tabular}

Significant $(p<0.01)$ and weak correlations were observed between the total PSQI scores with the total MRS ( $r=0.467)$ and with the somatovegetative $(r=0.43)$ and psychological domains $(r=0.417)$ and correlation very weak between the total PSQI score and the urogenital domain of the MRS ( $r=0.199)$, i.e., the worse the quality of sleep, the greater the severity of menopause symptoms.

Table 3 indicates that women categorized as bad sleepers, by PSQI, had higher scores of MRS and their domains than good sleepers, except in the indicator of muscle and joint problems $(p=0.39)$ of the somatovegetative domain and in the indicator of vaginal dryness $(p=0.40)$ of the urogenital domain.

\section{DISCUSSION}

When assessing quality of sleep in menopausal women and its association with symptoms related to menopause, the findings of this investigation pointed out aspects that deserve to be considered in the face of direct assistance to these women as well as in the scope of public policies aimed at this population.

In their study, the authors Silva, Rocha and Caldeira (2018) demonstrate that women with low education and income tend to have a negative self-perception of health. This result is in agreement with that found in the present study. This can result in a lack of knowledge about the changes that occur in the female organism during the climacteric and influence the participation of women in activities that benefit her health status, such as access to information, knowledge about health care and understanding of social rights ${ }^{(14)}$.

A research that aimed to outline the profile of women in climacteric enrolled in coverage areas of Family Health Strategy of São Luiz, Maranhão, as well as the biopsychosocial changes most mentioned by them, corroborated the importance of social determinants in the experience of this phase of the life cycle. The findings report that the majority of women had a low economic and educational level, factors that make them more vulnerable to understand information and guidance received, both from close relatives, friends, and health professionals. This finding was added to the difficulty of self-perception of women in relation to the climacteric, which can influence the dimension of self-care/search for health care at this stage of life ${ }^{(15)}$. Therefore, the low educational level unfolds in other dimensions of the social determinants of health; these related to women's living conditions in the climacteric, which greatly impacts their experience in this vital cycle.

In contrast, higher school levels and higher income provide opportunities for better eating practices, awareness and practice of physical activities and better housing conditions. Thus, the opportunity for greater performance of healthy activities, provided due to more time in school environment, has the consequence of combating diseases and conditions of morbidity and mortality, which would result in a worsening of quality of life $\mathrm{f}^{(7)}$. In the same logic, although it was not the subject of this study, the influence of absence of healthy lifestyle habits on the intensity of menopausal symptoms should be highlighted, denoting that social determinants of health related to lifestyle can also influence the symptoms of climacteric women.

The age of onset of menopause in the present study was similar to that of another study ${ }^{(16)}$. The average age at onset of menopause varies between countries. In India, for example, this average was 46.2 years $^{(17)}$; in the United States, 45.2 years old ${ }^{(18)}$; in Sweden, 
51 years old ${ }^{(19)}$; in Brazil, 49.4 years old ${ }^{(20)}$. The precociousness of menopause can cause the premature appearance of uncomfortable symptoms of this phase, impacting the quality of life of women.

The symptoms related to menopause in the present investigation were diverse. Although the multiplicity of these symptoms is evident, it was observed that the somatovegetative and psychological domains proved to be the most compromised in the present research, individualizing, in greater proportion, increase in the symptoms of shortness of breath, sweats and hot flash, muscle and joint problems (referring to the somatovegetative domain) and irritability and anxiety (referring to the psychological domain). Still in this perspective, it was found that the MRS symptoms reported most frequently were related to sleep, muscle and joint problems (referring to the somatovegetative domain), physical and mental exhaustion, depressed mood and irritability (referring to the psychological domain) and sexual problems (referring to the urogenital domain ${ }^{(19)}$. It should be noted, however, that differences can be found in the global MRS scores, which would impact the symptomatological levels presented. In the present study, the global MRS score found was higher than that of other studies $^{(16,21)}$; this difference can be explained by cultural, economic and social differences, influencing the signs and symptoms of women and modifying the score of the domains ${ }^{(22)}$.

Literature corroborates the findings of this investigation by showing that the most prevalent symptoms, in this vital phase, are expressed by hot flushes, insomnia, irritability, depression, muscle/ joint problems, sweating, headache, palpitation and those related to sexuality ${ }^{(23)}$. Thus, the appearance of these symptoms should be the focus of investigation and valorization by professionals.

This study showed that women who presented greater severity of signs and symptoms related to menopause reported greater impairment in sleep quality, which is why they were classified as poor sleepers through the PSQI. These data were also identified in another study, in which it was shown that sleep problems were reported with a higher prevalence among women with moderately severe symptoms assessed by the MRS ${ }^{(19)}$.

This finding is extremely important, since the impairment in sleep quality is not only a consequence of the exacerbated symptoms of menopause, but it is also a trigger element to exacerbate the severity of your symptoms, in which it was identified that poor sleep quality increases the risk 6 to 8 times in worsening women's quality of life ${ }^{(24)}$.

The cause of sleep disorders in menopausal women and the clinical signs related to menopause can be explained by the organic changes resulting from hormonal and organic dysregulations associated with ethnic, personal and environmental factors, and not only by the deprivation of the estrogen level(22); that is, the cause of changes in sleep quality must be seen as multifactorial, and this data is extremely important in nurses' assessment ${ }^{(24)}$.

Urogenital symptoms were moderately related to menopausal status, presenting a consensus as a result of the decrease in hormonal levels, which can lead to a loss of vulvovaginal mucosa roughness, with marked reduction in lubrication, generating genital dryness. Such urogenital changes modify the sexual activity of the affected patients, which promotes psychological disorders attributed to the menopausal transition; however, they are not directly related to sleep disorders ${ }^{(12)}$.
Although muscle and joint problems can cause pain, and these can lead to changes in sleep quality ${ }^{(25)}$, in the findings of the present study, these problems were not statistically significant. Differences between studies can be related with respect to several aspects, such as cultural, economic, social, psychological, environmental differences, health condition, type of study, assessed population, sample selection, presence of confounding variables and use of different instruments for pain assessment ${ }^{(26)}$.

In relation to the above, it is necessary to reflect not only on the health determinants and psychosocial factors that influence the life and menopausal symptoms of women, but also on the consequences of sleep deprivation in postmenopausal women's lives.

Sleep impairment is one of the factors that leads to a sedentary lifestyle, since the willingness to perform physical exercises is altered, therefore, constituting a risk factor for overweight and obesity, which are associated with the emergence of conditions chronic non-communicable diseases. In addition to coping with these conditions, changes in self-image associated with the discomfort of menopausal symptoms and socioeconomic and demographic issues can evolve to a depressive condition, thus evidencing the association of emotional disorders and poor sleep quality in climacteric women ${ }^{(27)}$.

The results of this investigation showed the importance of the management and treatment of sleep disorders and the severity of symptoms associated with menopause in health services. Therefore, it is possible to infer that this becomes imperative when considering that the majority of women with insomnia, at this stage of the life cycle, are not diagnosed, nor treated in health services ${ }^{(8)}$.

Thus, one must consider the importance of investing in nonpharmacological interventions, especially cognitive-behavioral therapies, and encouraging physical activity practices, which have had a positive effect on reducing the severity of insomnia and improving sleep quality ${ }^{(28-29)}$.

As it is a common and, in a way, neglected problem, the relevance of nurses' role in addressing these women is highlighted; nurses, in their clinical practice, should question the sleep profile and the degree of severity of symptoms and the impact of these dysfunctionalities on quality of life, analyzing them together with sociodemographic issues, in order to implement appropriate interventions aimed at correcting these changes ${ }^{(28-29)}$.

\section{Study limitations}

This study did not assess the presence of associated comorbidities, among the women studied, such as cardiovascular and musculoskeletal diseases. The cross-sectional design did not allow establishing the directionality of the associations found and the convenience sampling may have compromised the heterogeneity of the sample, limiting generalization of results.

\section{Contributions to nursing}

By identifying the presence of changes in the sleep pattern and the degree of severity of these symptoms, nurses can implement a series of nursing interventions aimed at improving the 
indicators of Sleep (0004) and Perimenopause Symptom Severity (2104) present in the Nursing Outcomes Classification ${ }^{(30)}$. To achieve these outcomes, it was possible to identify a series of nursing interventions proposed in the Nursing Interventions Classification ${ }^{(31)}$, such as Relaxation Therapy (6040), Music Therapy (4400), Exercise Promotion (0200), Anxiety Reduction (5820), and Energy Management (0180). The use of standardized language systems, based on the nursing interventions and outcomes classifications, can, in addition to qualify the service, better guide the assistance provided, offer continuous registration, provide a practice based on scientific foundations and provide future data that allow to assess the effectiveness of nursing actions in women with changes in sleep patterns.

The realization of health education practices and the planning and implementation of groups and programs aimed at early diagnosis, health promotion and prevention of diseases directed to women, in the age range of the prevalence of climacteric, proved to be potential interventions to minimize not only the causes, as well as the consequences of the damage caused by menopausal symptoms among these women.

\section{CONCLUSION}

In this study, it was identified that the majority of women with menopause had poor sleep quality and that the severity of menopausal symptoms in these women was associated with worse sleep quality, showing that the worse sleep quality, the greater the severity of menopausal symptoms.

Due to their high prevalence, sleep problems should be actively explored among women along with other symptoms of menopause, in order to ensure better health, quality of life and productivity for women in middle age.

Interventions in health education, promotion of exercise and relaxation practices, as well as the development of preventive and treatment strategies to relieve sleep disorders for these women, can bring great improvement with regard to these symptoms.

\section{FUNDING}

Federal Institute of Education, Science and Technology of South of Minas Gerais - IFSULDEMINAS.

\section{REFERENCES}

1. Miranda GMD, Mendes ACG, Silva ALA. Public policies challenges on the background of demographic transition and social changes in Brazil. Interface (Botucatu). 2017;21(61):309-20. https:/doi.org/10.1590/1807-57622016.0136

2. Ministério da Saúde (BR). Departamento de Ações Programáticas Estratégicas. Política Nacional de Atenção Integral à Saúde da Mulher: Princípios e Diretrizes[Internet]. 2004 [cited 2020 Jul 02]. Available from: https://bvsms.saude.gov.br/bvs/publicacoes/politica_nac_ atencao_mulher.pdf

3. Smail L, Jassin G, Shakail A. Menopause-Specific Quality of Life among Emirati Women. Int J Environ Res Public Health. 2020;17(40):1-9. https://doi.org/10.3390/ijerph17010040

4. Ministério da Saúde (BR). Departamento de Informática do SUS - DATASUS. Informações de Saúde, Epidemiológicas e Morbidade: banco de dados [Internet]. 2020 [cited 2020 May 12]. Available from: http://www2.datasus.gov.br/DATASUS/index.php?area=0206\&id=6942

5. He Q, Ren $Y$, Wang $Y$, Zhang F, Zhang $S$. The efficacy and safety of acupuncture for perimenopause symptom compared with different sham acupuncture control groups: a protocol of systematic review and meta-analysis. Medicine. 2020;99(10):1-6. https://doi.org/10.1097/ MD.0000000000019366

6. Gava G, Orsili I, Alvisi S, Mancini I, Seracchioli R, Meriggiola MC. Cognition, mood and sleep in menopausal transition: the role of menopause hormone therapy. Medicina. 2019;55(10):668. https://doi.org/10.3390/medicina55100668

7. Lima AM, Rocha JSB, Reis VMCP, Silveira MF, Caldeira AP, Freitas RF, et al. Perda de qualidade do sono e fatores associados em mulheres climatéricas. Ciênc Saúde Colet. 2019;24(7):2667-78. https://doi.org/10.1590/1413-81232018247.19522017

8. Robaina JR, Lopes CS, Rotenberg L, Faerstein E. Fatores psicossociais e socioeconômicos relacionados à insônia e menopausa: Estudo PróSaúde. Cad Saúde Pública. 2015;31(3):597-606. https://doi.org/10.1590/0102-311x00045014

9. Malta M, Cardoso LO, Bastos FI, Magnanini MMF, Silva CMFP. STROBE initiative: guidelines on reporting observational studies. Rev Saúde Pública. 2010;44(3):559-65. https://doi.org/10.1590/S0034-89102010000300021

10. Bertolazi NA, Fagondes SC, Hoff LS, Dartora EG, Miozzo ICS, Barba MEF, et al. Validation of the Brazilian Portuguese Version of the Pittsburgh Sleep Quality Index. Sleep Med. 2011;12(1):70-5. https://doi.org/10.1016/j.sleep.2010.04.02

11. Heineman LA, Potthoff $P$, Scheneider HP. International versions of the Menopause Rating Scale (MRS). Health Qual Life Outcomes. 2003;28(1):1-4. https://doi.org/10.1186/1477-7525-1-28

12. Freitas RF, Freitas TF, Vieira DR, Rocha NGS, Santos GS, Reis VMCP, et al. Qualidade de vida de mulheres climatéricas de acordo com o estado menopausal. Rev Unincor. 2015;13(1):37-47. https://doi.org/10.5892/ruvrd.v13i1.1840

13. Field A. Descobrindo a estatística usando o SPSS. 5.ed. Porto Alegre: Penso, 2020. 1072p.

14. Silva VH, Rocha JSB, Caldeira AP. Factors associated with negative self-rated health in menopausal women. Ciênc Saúde Colet. 2018;23(5):1611-1620. https://doi.org/10.1590/1413-81232018235.17112016

15. Caldas AJM, Silva CMM, Aquino DMC, Anjos FV, Vieira IO, Diniz JAR, et al. Vivenciando o climatério: aspectos socioeconômicos, físicos e emocionais. Enferm Bras. 2015;14(1):5-12. https://doi.org/10.33233/eb.v14i1.3702 
16. Lui Filho JF, Baccaro LFC, Fernandes T, Conde DM, Costa-Paiva L, Pinto Neto AM. Epidemiologia da menopausa e dos sintomas climatéricos em mulheres de uma região metropolitana no sudeste do Brasil: inquérito populacional domiciliar. Rev Bras Ginecol Obstet. 2015;37(4):1528. https://doi.org/10.1590/SO100-720320150005282

17. Ahuja M. Age of menopause and determinants of menopause age: A PAN India survey by IMS. J Midlife Health. 2016;7(3):126-31. https://doi. org/10.4103/0976-7800.191012

18. Malek AM, Vladutiu CJ, Meyer ML, Cushman M, Newman R, Lisabeth LD, et al. The association of age at menopause and all-cause and cause-specific mortality by race, postmenopausal hormone use, and smoking status. Prev Med Reports. 2019;15:e100955. https://doi. org/10.1016/j.pmedr.2019.100955

19. Rindner L, Strömme G, Nordeman L, Wigren M, Hange D, Gunnarsson R, et al. Prevalence of somatic and urogenital symptoms as well as psychological health in women aged 45 to 55 attending primary health care: a cross-sectional study. BMC Womens Health. 2017;17(128):18. https://doi.org/10.1186/s12905-017-0480-1

20. Silva LDC, Mamede MV. Prevalence and severity of menopausal symptoms in women with coronary artery disease. Rev Pesqui Cuid Fundam. 2020;12:305-12. https://doi.org/10.9789/2175-5361.rpcfo.v12.6755

21. Monterrosa-Castro Á, Paternina-Caicedo ÁJ, Herazo-Acevedo E, Oviedo-Acevedo HC, Campo-Arias A. Validity and reliability of menopause ratingscale in Colombian indigenous population. Duazary. 2017;14(1):8-15. https://doi.org/10.21676/2389783X.1737

22. Monteleone P, Mascagni G, Giannini A, Genazzani AR, Simoncini T. Symptoms of menopause: global prevalence, physiology and implications. Nat Rev Endocrinol. 2018;14(4):199-215. https://doi.org/10.1038/nrendo.2017.180

23. Pitombeira R, Lima FET, Magalhães FJ, Custódio IL, Oliveira SKP. Sintomatologia e modificações no cotidiano das mulheres no período do climatério. Cogitare Enferm. 2011;16(3):517-23. https://doi.org/10.5380/ce.v16i3.20913

24. Frange $\mathrm{C}$, Hachul H, Hirotsu C, Tufik S, Andersen ML. Insomnia with musculoskeletal pain in postmenopause: associations with symptoms, mood, and quality of life. J Menopausal Med. 2018;24(1):17-28. https://doi.org/10.6118/jmm.2018.24.1.17

25. Lytsy P, Larsson K, Anderzen I. Health in women on long-term sick leave because of pain or mental illness. Int J Rehabil Res. 2015;38(1):27-33. https://doi.org/10.1097/MRR.0000000000000080

26. Dedicação AC, Sato TO, Avila MA, Moccellin AS, Saldanha MES, Driusso P. Prevalence of musculoskeletal pain in climacteric women of a Basic Health Unit in São Paulo/SP. Rev Dor. 2017;18(3):212-216. https://doi.org/10.5935/1806-0013.20170104

27. Gonçalves JTT, Silveira MG, Campos MCC, Costa LHR. Overweight and obesity and factors associated with menopause. Ciênc Saúde Colet. 2016;21(4):1146-55. https://doi.org/10.1590/1413-81232015214.16552015

28. Guthrie KA, Larson JC, Ensrud KE, Anderson GL, Carpenter JS, Freeman EW, et al. Effects of pharmacologic and nonpharmacologic interventions on insomnia symptoms and self-reported sleep quality in women with hot flashes: a pooled analysis of individual participant data from four MsFLASH Trials. Sleep. 2018;41(1):1-10. https://doi.org/10.1093/sleep/zsx190

29. Caretto M, Giannini A, Simoncini T. An integrated approach to diagnosing and managing sleep disorders in menopausal women. Maturitas. 2019;128:1-3. https://doi.org/10.1016/j.maturitas.2019.06.008

30. Moorhead S, Johnson M, Maas M, Swanson E. Classificação dos Resultados de Enfermagem (NOC). [Internet]. São Paulo: Elsevier; 2010[cited 2020 Jul 02]. 712 p. Available from: http://www.faesb.edu.br/biblioteca/wp-content/uploads/2020/03/NOC-Digital.pdf

31. Bulechek GM, Butcher HK, Dochterman J. Classificação das Intervenções de Enfermagem (NIC). [Internet]. São Paulo: Elsevier; 2010[cited 2020 Jul 02]. 640 p. Available from: https://www.biosanas.com.br/uploads/outros/artigos_cientificos/14/0ac4055be9a07e3df54c72e9651c5 89e.pdf 